\title{
Agritourism - From Additional Income to Livelihood Strategy and Rural Development
}

\author{
Mathilde Schmitt ${ }^{*}$ \\ Austrian Academy of Sciences, Mountain Research: Man and Environment, Technikerstr. 21a, ICT, A-6020 Innsbruck, \\ Austria
}

\begin{abstract}
During the Romantic period, the Franconian Jura in northern Bavaria, Germany, was discovered as an attractive landscape with aesthetic value. The diversified cultural landscape (rocks, forests, and farmland) and its seasonal variations in land cover are appreciated by tourists to this day, albeit in different form and use made of the scenic beauty. With the modernization and restructuring of agriculture in the 1970 s, farming families increasingly seized the opportunity to play a role in rural tourism. In the last three decades, offering holidays on the farm as well as direct sales of their own valueadded farms' products have provided additional alternative incomes.

The article draws on a longitudinal study (1977 - 2007) which focused on the farming women's agency, coping strategies, visions and wishes against the dynamic changes of the agricultural sector. The rich data enabled the author to give an overview of tourism-related activities within the sample from the point of view of the farming women as well as to construct two case studies that looked at the role of agritourism within the pluri-activities for the women involved and the multifunctional orientation of their farms. While agritourism has become an important permanent livelihood strategy for some farming families, it remains an additional income for others. Either way, it has turned out to be a source of women's growing self-confidence as well as a sustainable ingredient of regional development.
\end{abstract}

Keyword: Agritourism, restructuring of agriculture, feminization, women's visibility, peasant principle, pluriactivity, multifunctionality, rural development.

\section{INTRODUCTION}

In June 2009, the German Federal Parliament passed a resolution to improve agri- and rural tourism. The representatives emphasized its significance for rural development as well as for a strong domestic tourist industry and pointed out the sustainable, environmentally sound and affordable aspects of agri- and rural tourism. The negotiations at this level show the growing significance of the topic for the various spheres of the political economy. For the farming families, too, the role and the variety of forms of their businesses have changed over time.

The agritourism developments of the last three decades must be assessed in the light of the dynamic restructuring processes of the whole agricultural sector, which are without parallel in rural history. The farming families in Germany have had to face several challenges with the introduction of milk quotas, CAP reforms and additional changes in the wake of the reunification in 1989, along with a steep rise in the average size of farms. In 1992, new environmental regulations followed on from the UN conference on environment and development in Rio, with global deregulations added by the General Agreement on Tariffs and Trade in 1994. In the 1990s, the EC programmes for rural development (LEADER, EAFRD) and the Bavarian programme for cultural landscapes (KULAP) set new development standards: from market-oriented production to rural development

*Address correspondence to this author at the Austrian Academy of Sciences, Mountain Research: Man and Environment, Technikerstr. 21a, ICT, A-6020 Innsbruck, Austria; Tel: +43-512-5074946; Fax: +43-5125074960; E-mail: mathilde.schmitt@uibk.ac.at with a focus on and a reassessment of the multifunctionality of agriculture. With the new millennium, attention centred on the agrarian cultural turn (Agrarwende) towards an environmentally sound agriculture.

In response, the farming families had to find coping strategies over and over again and - following John Berger $[1]^{1}$ who characterizes them as a "class of survivors" - to prove their resilience as they have had to do for many centuries. Agritourism in its different facets ${ }^{2}$ turned out to be quite a successful policy - first for smaller and part-time farms, after a change in EC policies also for larger farms. As a result of the changing economic and political conditions, the agritourism businesses had to be adapted repeatedly during the agricultural restructuring processes if they were to provide a promising additional income. This ability to adapt successfully cannot be taken for granted. It is also a question of the family's and farm's available resources.

This article looks at the way in which farming families have grasped the opportunity to play a role in rural tourism with the modernization and restructuring of agriculture that began in the 1970s. It draws on a longitudinal study (19772007) which focuses on the farming women's agency, coping strategies, visions and wishes against the dynamic changes of the agricultural sector. The rich data enabled the

\footnotetext{
${ }^{1}$ John Berger, author, essayist and expert on the peasants' life in a French mountain village.

${ }^{2}$ I agree with Bohuslava Boučková [2] who defines agritourism as a form of rural as well as sustainable tourism. "It refers to the act of visiting a working farm or any agricultural, horticultural or agribusiness operation for the purpose of enjoyment, education, or active involvement in the activities of the farm or operation." (p. 7)
} 
author to give an overview of tourism-related activities within the sample from the point of view of the farming women as well as to construct two case studies that stand for two development paths within the context of agritourism which were identified on the basis of the quantitative data. These two case studies looked at the role of agritourism within the multifunctional orientation of their farms and the pluri-activities of the women involved.

The author is aware that Sally Shortall's suggestion [3] to include both the individual and the household as a unit of analysis if you want to understand the farming family's attitudes and decisions when they face new economic or social conditions, has only partly been realized; the men's voices are missing. To take the women's perspective is justified by the fact that women play a key role in diversifying activities on the farm to secure its survival [4]. This is especially true for agritourism, processing and direct marketing of one's own produce.

While agritourism has become an important permanent livelihood strategy for some farming families, it remains an additional income for others. Either way, it has turned out to be a source of women's growing self-confidence as well as a sustainable ingredient of regional development.

\section{THEORETICAL FRAMEWORK}

The theoretical framework used in the longitudinal study was based on the theory of creativity of action developed by Hans Joas [5]. He assumes that human actions are initiated and reorientated by people's own impulses as well as by the changing conditions of given situations. Successful action is only possible by close and flexible reference to situational and particular contexts. Joas does not identify a specific type of action as creative, rather, he claims a creative dimension for any human action.

For this article the approach of creativity of action is combined with Jan Douwe van der Ploeg's theory of "the new peasantries" [6]. He emphasizes agency as the central characteristic of the 'peasant condition' and singles out the struggle for autonomy within the social context of dependency, marginalization and deprivation as an essential aspect of peasant farmers' agency. The 'peasant principle', which he sees as an "emancipatory notion", implies "that particular worldviews and associated courses of action matter. It stresses the value and satisfaction of working with living nature, of being relatively independent, of craftsmanship and pride in what one has constructed. It also centres on confidence in one's own strengths and insights." (p. 274) These attitudes encourage an involvement in other, nonagrarian, activities like agritourism, which "feed back into and strengthen the resource base, improve the process of coproduction, enlarge autonomy and, thus, reduce dependency." (ibd. 23). In addition, the (women) farmers' involvement in agritourism and direct marketing turns out to reconnect "farming again to society, nature and the interests and prospects of the direct producers," (ibd. 157) and in this way farming families are becoming drivers of rural development activities.

The difficulty with the theory of "the new peasantries" is it's continuously androcentric perception. If at all, women (and children) occur as victims of patriarchy (ibd. 274). The farming women's productive and reproductive activities for the continued development of the farm businesses, their key role in securing the farm families' survival and the peasantdriven rural development are not even mentioned. This article will try to balance this deficiency by focusing on women's agency regarding their contributions to agritourism.

An important input regarding pluriactivity is provided by the concept of feminization of agriculture as Heide Inhetveen and Mathilde Schmitt [7] have developed it. They emphasize the female farmers' ability to draw on knowledge and skills they have gained through education and experience, as well as to identify and exploit earning opportunities in the tertiary sector by professionalizing their activities on the farm (e.g. in opening a bed \& breakfast, or a café on the farm or a party-service).

They identified a female core of the secondary business consisting of a mother and daughter or a mother-in-law and daughter-in-law, extended by the recruitment of other family members as needed. The commercialization of the female economy was thus based on existing personal and social resources, leading to a new reciprocal network of female family members and their relatives. It remained embedded in the traditional family enterprise, it necessitated and promoted family enterprise thinking and behaviour. In some cases, but not necessarily, it also shifted power relations on the farm in favour of women.

\section{METHODOLOGICAL FRAMEWORK}

The data used for this article are drawn from a longitudinal study of farming women conducted in 1977, 1997 and 2007 [7, 8]. A large-scale base line and two follow-up studies were carried out in 63 municipalities of Bavaria, Southern Germany. A wealth of quantitative as well as qualitative data allows us to address the issue of agritourism from the women's perspective over 30 years.

In 1977, using a semi-standardized questionnaire, 134 farm women between the ages of 18 and 66 were interviewed about various aspects of their biographies, their everyday lives, their work and their coping strategies vis-àvis the challenges of modernization in agriculture. The sample was put together from small- and medium-sized farms run part- and full time, women of different ages and at different stages of family life involved in the farming business, and more central and more remote areas with better/worse infrastructure, job market opportunities and transport infrastructure.

In 1997 , we visited 128 of these women - only six had died since the first survey - and asked them about changes in their attitude and patterns of action with regard to the accelerating agricultural restructuring process. Biographical interviews with a selected subset of 26 women were used to analyse how social and structural changes during the past 20 years were reflected in the individual lives of farm women. In addition we used semi-structured interviews with 19 experts to assess the relevant general conditions for the women, their farms and the region. 
In 2007, a second update of farms and individual lives was conducted, again using a semi-standardized questionnaire. If the farm women had died (25 cases), we contacted other family members.

\section{STUDY AREA}

The Franconian Alb, better known as Franconian Switzerland, is an upland in northern Bavaria which belongs to one of the biggest German nature parks, with 2,300 square kilometres. The peripheral region with an absolute altitude between 300 and $500 \mathrm{~m}$ is located between three key cities that can be reached from the investigated farms within 15 to 60 minutes. The cultivated landscape is mainly used for agriculture and forestry and characterized by great variety of landscapes and rich diversity of species. On average it enjoys 1680 sunshine hours per year.

The Franconian Switzerland's diverse cultural landscape (rocks, forests, and farmland) and its seasonal variations in land cover have been appreciated by tourists to this day, but with several changes in appreciation and use made of the scenic beauty. Besides good hiking conditions, the area is popular for its rock climbing and canoeing options. It is one of the oldest holiday areas of Germany [9]. It was discovered as an attractive landscape with aesthetic value more than 200 years ago, during the Romantic period. The most fascinating tourist locations are the hundreds of caves all over the area. Guided tours are available in three big limestone caves with columns of limestone, stalagmites and stalactites of various shapes and sizes. In addition to the highly structured landscape, a large number of archaeological monuments are evidence of very early settlements from the Bronze and Iron Ages, and more than 150 castles and ruins from medieval times. The region also boasts a high density of small breweries and distilleries, which produce mainly for local consumption but are increasingly integrated into tourism concepts.

\section{POLITICAL FRAMEWORK}

In Germany, the promotion of rural tourism for regional development can be traced back to the 1960s. In Bavaria, to which the study area belongs, the Ministry for Agriculture, Food and Forestry released a development scheme for farm holidays as early as 1969 . It reached its peak in the middle of the 1970s and was abandoned in 1983 [10]. Agri- and rural tourism again appeared on the agenda when the European Community policies for rural areas were introduced with the reform of the structural funds in 1988 and adapted in 1993. EC structural policy initiated a reorientation from a policy based on sectors towards an integrated policy for rural development that involved all sectors. Within the framework of special EC programmes (LEADER I, II, +; EAFRD) and/ or national programmes (RegionenAktiv), numerous local action groups on rural tourism and cooperation were founded all over Germany. Moreover, farming families could apply for objective 2 (former $5 \mathrm{~b}$ ) regional subsidies to professionalize their agritourism and direct marketing offers.

While the importance of agritourism in Germany all but exploded during the 1990s, the number of farm holidaymakers dropped more than 30 percent between 2003 and
2006 and around 20 percent later on. The duration of the average stay also decreased [4]. Agricultural ministries reacted to this phenomenon by providing special expansion services, workshops and moderated groups to exchange experiences about agritourism, direct marketing, catering etc. Other institutional coping strategies were the development of quality markers by the DLG (Deutsche Landwirtschaftsgesellschaft, German Agricultural Society) and an annually organized competition for the top ten agritourism quality hosts.

Contrary to some parts of the Alps, Franconian Switzerland has not experienced any kind of landscape overutilization through mass-tourism to date. Since the reunification of Eastern and Western Germany (1989/90) and the establishment of a "New Franconian Seenland", a holiday region around several reservoirs created in the 1990s, Franconian Switzerland had to face a bigger drop in demand for its holiday offerings in general. To manage the crisis, new leisure facilities were established (e.g. golf courses, spas, Nordic walking centre), the regional tourist offices cooperated and, in 1996, were centralized as 'Tourismuszentrale Fränkische Schweiz'. A Leader+ local action group was founded in 2001 to set up an integrated development plan "Kulturerlebnis Fränkische Schweiz" (Franconian Switzerland as cultural experience) [11].

\section{FARM AND FARM-BASED DEVELOPMENTS}

Faced with the developments within the agri-food sector and the ongoing CAP reforms of the European Union, individual farming women and their families chose a variety of paths. The quality of their 'survival' [1] depended on their ability to come to terms with the restructuring conditions and to respond to them according to their own needs. What does this look like in detail?

\section{A "Class of Survivors" and its Striving for Autonomy}

101 of the former 134 agricultural enterprises were still active farms in 2007. In most cases (90\%) a generational change - sometimes even two - had taken place. As a consequence, the farming families had not only to cope with the challenges of the agricultural framework but also with their family restructuring. 33 farms $(25 \%)$ had been abandoned within the last three decades. In comparison with the official figures for that period $(57 \%$ for West Germany, 52\% for Bavaria), this surprising result confirms John Berger's [1] characterization of the farmers as a "class of survivors".

The second striking result of our longitudinal study was the percentage of farms run as a part-time concern which had increased from $42 \%$ in 1977 to $69 \%$ in 1997 to $78 \%$ in 2007 , i.e. it had almost doubled. The striking discrepancy with official figures (55\% for Germany and $54 \%$ for Bavaria) was due to the specific structure of the sample. It contained many rather small farms in the regions with the highest numbers of part-time farms in Germany resp. Bavaria $[12,13]$. The fact that these small businesses had not closed down in the studied period shows how highly the farming families prize this life-style across generations.

Only in a few cases did the change from full-time to parttime farming happen as a result of the farmers' or women 
farmers' decisions to take up an off-the-farm job. In most cases it occurred when the farm was passed on from one generation to the next which earns its principal income off the farm. This strategy of part-time farming offers the young generation, which had largely still been traditionally socialized, the continuation of the peasant principle.

While most of the farming women we interviewed could not or no longer conceive of training for non-agricultural jobs, it was conceded as a matter of course to their children of both sexes. The mothers would still ideally see their children doubly qualified, both for farming and for a "proper job", as insurance against all eventualities that might arise. Our findings confirm Patricia O'Hara [14] who accentuated Irish farm women's high educational aspirations and their influence on their children's educational and vocational decisions.

The increased commonness of combined forms of earning and female employment in rural areas is beginning to produce changes in the roles of the sexes - quite slowly in our sample. Such developments underline the necessity of "gender role flexibility", as has been identified by Ruth Rossier [15] as a precondition for successful continuation of farming businesses in Switzerland and by Monica Gorman for Ireland [16].

\section{Strengthening the Resource Base Through Pluriactivity}

Besides changing to part time farming most "survival strategies" of the farming families within the last thirty years were designed to create, stabilize and expand their resource basis, which for van der Ploeg is the essence of the peasant principle. " $\ldots$ the search for, and construction of, additional value added is an important characteristic of the peasant economy." [6] (p. 159) In contrast to the business strategy of specialization, peasant farming favours diversification and pluriactivity (see Table 1). Even some of those women farmers who did realize or consider specialization in 1977 (e.g. pig rearing, dairy farming) in the end had more confidence in diversified production and earning modes. ${ }^{3}$ Agritourism has proved to be an important source of income over the last 30 years, in addition to processing and direct marketing of their own produce.

\section{Table 1. Farm-Based Additional Income}

\begin{tabular}{|c|c|c|c|c|c|c|}
\hline & \multicolumn{2}{|c|}{1977} & \multicolumn{2}{c|}{1997} & \multicolumn{2}{c|}{2007} \\
\hline & Farms & $\%$ & Farms & \% & Farms & \% \\
\hline \hline Active farms & 134 & 100 & 105 & 100 & 101 & 100 \\
\hline with direct marketing & 102 & 70 & 82 & 78 & 56 & 56 \\
\hline with agritourism & 17 & 13 & 21 & 20 & 19 & 18 \\
\hline $\begin{array}{c}\text { with agritourism + } \\
\text { direct marketing }\end{array}$ & 13 & 10 & 12 & 11 & 11 & 11 \\
\hline
\end{tabular}

Source: Author's own data.

By establishing additional sources of income, the farming families proved their capability for creative responses [5].

\footnotetext{
${ }^{3} \mathrm{~A}$ survey conducted by the Agrarsoziale Gesellschaft, Göttingen, emphasizes the financial and psychological importance of these additional incomes for the farming families [17].
}

The diversity and widening of sectors and types of business demands and encourages specific skills at the level of agency: the farming families had to adapt to new situations flexibly and did so successfully. Creativity and improvization were newly required capabilities for utilizing new resources. Besides, pluriactive peasant farming is unthinkable without the will and the ability to carry out many activities in parallel and to synchronize them. It is precisely this ability, combined with a strong work ethic that many farming women of the sample's generation bring to this situation. Their competence guarantees the continued existence of the farms under any conditions.

We recognize that the agritourism sample did not develop evenly. Some of the farming families quit agritourism, while others started up with this kind of business between 1977 and 2007 (see Table 2). In 2007, holiday apartments were increasingly offered instead of bed and breakfast, which meant less work for them.

Table 2. Development of Agritourism Businesses

\begin{tabular}{|c|c|c|c|c|c|c|}
\hline & \multicolumn{2}{|c|}{$\begin{array}{c}\text { Agritourism } \\
\mathbf{1 9 7 7}\end{array}$} & \multicolumn{2}{c|}{$\begin{array}{c}\text { Agritourism } \\
1997\end{array}$} & \multicolumn{2}{c|}{$\begin{array}{c}\text { Agritourism } \\
\mathbf{2 0 0 7}\end{array}$} \\
\hline \hline $\begin{array}{c}\text { Start-up before } \\
1977\end{array}$ & 17 & $100 \%$ & 13 & $62 \%$ & 12 & $63 \%$ \\
\hline $\begin{array}{c}\text { Start-up 1977 - } \\
1997\end{array}$ & - & - & 8 & $38 \%$ & 6 & $32 \%$ \\
\hline $\begin{array}{c}\text { Start-up 1997 - } \\
2007\end{array}$ & - & - & - & - & 1 & $5 \%$ \\
\hline Total & 17 & $100 \%$ & 21 & $100 \%$ & 19 & $100 \%$ \\
\hline
\end{tabular}

Source: Author's own data

The strategies to cope with the drop in demand for agritourism in the 1990s that we found in our sample included renting the holiday apartments to itinerant builders and sales agents who use the favourable accommodation. As a positive side-effect, this ensured a greater use of the facilities off season. New business ideas during the last decade had mainly been developed with regard to the processing and direct marketing of a farm's own products (e.g. specific chocolate or liqueur production and tastings, direct sale of meat and speciality sausages, seasonal handicrafts) or to group-oriented recreation and entertainment activities and leisure services for the guests (e.g. guided cave tours). In addition, advertising for such activities had been intensified and the regional tourist offices were coordinating campaigns. At fairs and markets, four committed female farmers of the sample promoted together their respective regions all over Germany.

The main principle of all hosts was to confidently rely on the bookings of their regular guests and to keep on working - according to John Berger [1] a typical sign of their peasant attitude: "If there is one aspect of their lives that never changes it is the necessity of working." (p. 284) Also Alexander Tschajanow refers to this strategy as a specific peasant family farmers' characteristic. [18]

The farm-based activities had become an important additional income, regardless of the chosen farming scheme, but mainly for part-time farming families: 
Table 3. Agritourism and the Farming Scheme

\begin{tabular}{|c|c|c|c|c|c|c|}
\hline & \multicolumn{2}{|c|}{1977} & \multicolumn{2}{|c|}{1997} & \multicolumn{2}{|c|}{2007} \\
\hline \multirow{2}{*}{ Full-time farming } & 60 & 6 & 34 & 2 & 22 & 3 \\
\hline & $45 \%$ & $35 \%$ & $25 \%$ & $15 \%$ & $16 \%$ & $16 \%$ \\
\hline \multirow{2}{*}{ Part-time farming } & 74 & 11 & 71 & 16 & 79 & 13 \\
\hline & $55 \%$ & $65 \%$ & $53 \%$ & $80 \%$ & $59 \%$ & $68 \%$ \\
\hline Farming abandoned & & & $22 \%$ & $5 \%$ & $25 \%$ & $16 \%$ \\
\hline \multirow{2}{*}{ Total } & 134 & 17 & 134 & 21 & 134 & 19 \\
\hline & $100 \%$ & $100 \%$ & $100 \%$ & $100 \%$ & $100 \%$ & $100 \%$ \\
\hline
\end{tabular}

With regard to the extent of farming activity, the agritourism business seems to correlate with the worked acreage of the farm, which, both in 1977 and in 2007, was neither very small nor very big: fifteen families farmed between 5 and 19 ha. The very few others worked between 20 and 50 ha. Whereas at first smaller and part-time farms in peripheral regions introduced and established agritourism on a small scale as additional income, "Nearly always, it is the peasant farms that function as the point of departure (and as the resource pool) for the creation of such new multifunctional entities" [6] (p. 121), during the 1990s a few bigger farms also began to realize their potential for agritourism (see Table 3) to improve their future perspectives under changing EC policies - a phenomenon that can also be observed in other parts of Germany [19].

Nobody mentioned any connection between starting up an agritourism business and any particular official development or funding scheme but an indirect and long-term influence of agricultural policy can be identified. This refers to Ruth Gasson's research in Britain in the 1980s and 1990s [e.g. 20, 21] which showed that agricultural policy was driving farm women's adoption of farm holiday initiatives and thus transforming the family farm and women's work on it.

\section{Women's Substantial Contribution}

In our sample it was the women of the farming families who - in line with the traditional labour division on most of the farms - carried the responsibility as well as the workload of the agritourism, processing and direct marketing activities in addition to their farm, care, subsistence and other house work. The men were more or less involved, depending on their age and main activities.

Across the three decades, the interviewed farming women often turned out to be more open and readier to experiment than the men on the farm. This becomes very clear in several cases and has been confirmed by studies in other countries, e.g. Sarah Johnsen [22] for New Zealand and Monica Gorman [16] for Ireland. Women play a key role in diversifying earning opportunities to secure the survival of the farm.

In twelve instances, a new type of non-agricultural production or service was introduced on the farm due to an initiative or with the support of newly arrived daughters-in- law, who brought with them good education and the experience of working in other sectors of the economy. The older generation did not always support such initiatives. In these cases, a clear division of labour helped to diffuse the conflict.

The results presented here point to the significance of agritourism, processing and direct marketing of one's own produce for the survival of farming, albeit from a bird's view. They raise questions and assumptions that would need to be clarified using qualitative data. The complex aspect of agency, the approach of farming women to the challenges of everyday operation and business development can only become clear through theme-centered interviews and through analysing stories of successful and failed projects. The interpretation of such narratives lays open the self-perception and action repertoire of farming women, which is the result of their lifelong experiences and observations.

\section{TWO AGRITOURISM DEVELOPMENT PATHS}

The two cases presented below stand for two development paths within the context of agritourism, which we were able to identify from the quantitative data. They represent different concepts of multifunctionality in agriculture. Both aim to engage in pluriactivity by diversifying farm income to make the household less reliant on the farm's commodity production income. What varies is the range of goods and services offered and the investment and maintenance costs involved in providing them. In some cases, they are working their farms to produce a 'holiday' retreat for guests and visitors (a), and in others they supply 'novelty' food products for a local and regional niche market plus marketing a farm gate experience (b).

(a) In one strategy, represented by Wanda C, short-term accommodation in a rural setting is being sold as a farm holiday. This strategy involves low input and maintenance costs for the farm family but it also brings low returns. Twelve families of the sample sold this type of accommodation to create an additional income and boost overall family earnings. The basis for this business idea is slight adaptation in response to the changing needs of customers, e.g. from bed \& breakfast to holiday apartments or offering group-oriented recreation and entertainment activities for the guests. 
(b) The second diversification strategy, represented by Martha B, involves 'entertaining' guests for a shorter period of time by offering them a tasting and/or shopping experience on the farm. The product range includes farm-produced, value-added products and additional local products in order to enrich the visitors' experience. This approach tends to involve more comprehensive refurbishment and investment. An important dimension of this strategy is the volume of visitors passing through the farm to make purchases on a regular basis. In recent years, eight families of the sample realized and professionalized agritourism on their farm as well as processing the farm's produce and marketing it directly, always in a form of cross-marketing. Not only did they expand family labour but they even hired foreign labour. Agricultural branches such as dairy production were reduced or abandoned. One of the consequences was a changed self-image of the women involved, who stressed that they no longer fitted the role model of a typical farming woman. The type and extent of advertising for the farm products and services had also changed. These farms had developed their own websites as a matter of course.

\section{CASE STUDY WANDA C}

"It's as if some of them are family"

When we interviewed Wanda C in 1977, she was 40 years old, married and had a 19 year old daughter who worked on the counter in a butcher's shop. Wanda C had grown up on the outskirts of a large town nearby. When she was 20 years old, she had married a farmer whose small, highly diversified, farm ( 8 ha) was situated in a highland region nearby. Although her aspiration had been to become an engineering drafts person, she learned to enjoy being a farm woman and to handle the agricultural machinery. In the beginning she had worked off the farm, first as a seamstress, then in a metal processing factory. After six years she had given up her job when her husband got an offer to work off the farm as a papermaker's assistant. To decrease the work load of the highly diversified farm, they specialized into pig breeding. In 1973, they had decided to run a bed \& breakfast on the farm for an additional income. The farm woman enjoyed looking after and communicating with the guests as a welcome change and planned to develop this business. As Wanda $\mathrm{C}$ received emotional and mental inspiration from the farm holiday business, she and her family did not quit it when her mother-in-law's illness required increasing care or when she herself developed a lung tumour in 1986.

In 1997, when we revisited her, Wanda $\mathrm{C}$ had recovered well from her life-threatening disease. The daughter who occasionally worked part-time as a sales assistant had taken over the farm business a year before when the farmer had retired from his off-farm job. Both he and the farm woman stayed involved with the farm work. Since 1983 they had focused on keeping horses, bees and just a few sheep, goats, ducks, geese, hens and rabbits for their guests' experience and enjoyment as well as for their own subsistence. Wanda $\mathrm{C}$ and her husband were responsible for keeping all the small animals. The farmed land was transformed into meadows.
Direct marketing was limited to honey and homemade jams for the holiday guests. Holiday apartments had replaced the bed \& breakfast, and in one of the apartments the 18 year old granddaughter, who had trained as a legal secretary, had established her own realm. Wanda C's husband supported the agritourism business by providing typical ancient farming implements for decoration, which he loved to hunt for on flee-markets.

The good cooperation between the three generations was based on a precise division of labour and a high tolerance of the individual interests. The farming family also did not hesitate to ask for advice and support from the local agricultural office as needed.

In 1992, Wanda $C$ had increased her engagement in agritourism and, together with committed female farmers, had promoted their respective regions all over Germany at fairs and markets. In addition, they had developed and coordinated special entertainment activities for guests during summertime. To advertise those, Wanda $\mathrm{C}$ had designed a leaflet, which her son-in-law processed further on the computer.

In 2007, when we interviewed Wanda C again, her daughter was still busy with renting out holiday apartments and offering special free-time activities for children and experience-driven events, supported by a neighbour who was trained as a horseriding instructor. A kind of pergola was erected in the farmyard where the guests could lounge around. Wanda $\mathrm{C}$ had abandoned her promoting activities. She proudly presented a certificate of honour that she and her husband had received from the tourist association for 20 years of farm holidays. They had celebrated this jubilee together with some of their regular guests. "We know their relatives, they know our whole kin, it's as if, like some of them are family."

By introducing the case study Martha B, I would like to show the second interesting development path in rural tourism, based on quite different motivations and decisions as compared to Wanda $\mathrm{C}$.

\section{CASE STUDY MARTHA B}

\section{"You set up a business and you build on it"}

When we interviewed Martha B in 1977, she was 30 years old, married and had five children aged between two and eleven years. The farm, which she had inherited from her parents, still had 12 cows, but had given up keeping pigs. Cropping on the 28 hectares farm was highly diversified. Martha B identified herself strongly with the farm, she was especially proud to be her 'own master'. Together with her mother she kept a large garden, preserved fruits and vegetables, and sold products from the farm and garden, such as milk and fruit, directly to customers. The additional income earned by her husband, who worked part-time in the local agricultural machinery pool, was considered a temporary expedient.

In 1997, when we revisited Martha B, the cropped area had been increased to 40 hectares by renting and buying land. The farming family's main goal of increasing the milk quota and expanding dairy activities could not be achieved within the new agrarian-policy framework. Instead, they 
looked for new perspectives. The heir to the farm took advantage of the opportunity to improve his education and get a job in the accounting office at the local farmers' association. Martha B and her daughter-in-law worked together, utilising available materials, personnel and qualifications in the house and on the farm, to develop a new concept for the production and sales of their farm products. In addition to fruit schnapps, they produced different types of liqueur, made from produce grown on the farm, using a process they had developed themselves. In addition, products that had formerly been primarily produced and processed by the women on the farm within the framework of a subsistence economy, were now commercialized. Already in 1982, they had decided to renovate the living quarters and integrate a holiday apartment for providing another farm-based income.

In 2007, when we visited the farm once again, the property had again been creatively and tastefully modernized. Solar panels were installed on the roofs. In one of the restored outhouses they offered specialities produced at the farm as well as superior regional products. They were receiving customers on the farm not only from the near vicinity but also in the form of large parties of tourists. A new distillery, a professional kitchen and a well-furnished tasting room had been integrated into the ensemble. The family had abandoned dairy farming and was growing renewable primary products, as well as 2 ha of berries and fruits, which they processed and marketed. The business is participating in many EU support programmes.

The former working team of the farm woman, her son (the farm successor) and his wife, had been enlarged by a daughter, another daughter-in-law and a neighbour. The agricultural enterprise shows an interesting paradox: it had developed into a women-run family farm in terms of their influence and presence, but it is officially still headed by a male, the single heir of the farm, Martha B's son. Martha B's husband had died, aged 57. The former holiday apartment was now used for the family's personal needs. Martha B's family decided to benefit from tourism by expanding and commercializing the commodities produced by the women.

\section{CARVING OUT THE WOMEN'S SPHERES OF ACTION}

The two biographies show that even during the decades of "grow or go" the desire for autonomy and self-determination - for van der Ploeg [6] an essential aspect of peasant farmers' agency - continued to be the driving force that gave direction to the women farmers' actions. Efforts were made to keep this dream of freedom and autonomy alive even through precarious times, as can clearly be seen in the case of Wanda C. She, Martha B as well as other farming women of the sample could successfully cope the restructuring of agriculture for the last three decades if they managed to balance several spheres connected to their family farms' developments.

\section{Balancing Women's Increasing Visibility and Patriarchal Ideology}

As can clearly be seen in the two case studies, it is often the traditionally feminine area of housekeeping that becomes commercialized and valorized when farms are branching out into new earning sectors to strengthen their resource base. It is a form of "feminization of agriculture" [7] or "bridging the gap" between their own interests and resources and the changing framework in which they operate [5]. In 1983, Carolyn E. Sachs [23] could still describe women in farming as "invisible farmers" whose contribution to the survival of farming families and businesses were undervalued. Both financially and conceptually, they have since become much more visible.

If agritourism and direct marketing businesses become increasingly visible in the form of buildings, customer flows and increased revenue, while the significance of agricultural businesses on the farm diminishes, then the involved men and women are faced with having to rethink their identities and gender relationship. Many are finding this difficult as one can see from their concept of autonomy. "Remaining your own boss" can be confirmed as one of the main principles of both farming families. The strive for autonomy is limited in that the objective is not the autonomy of the individual (at least of the female individual) but that of family and farm. More than a few farming women of the sample help maintain the "patriarchal façade" that Ilse Modelmog identified [24]. For English farming women, Sarah Whatmore [25] also showed "some of the ways in which the patriarchal gender ideologies associated with the family labour process are reproduced through women's own subjective experience and taken up in the discursive positions which they adopt" (p.86).

In the second case, economic and personal developments support a female independence that links traditional values (survival of the farm; children are required to join in the work occasionally, etc.) with modern perspectives (free choice of profession and individual live choices for the children). Striking in this context is the "continual process of negotiation between women and men within the family farm" [26] (p. 24), which has been not only noted in recent studies, e.g. Sally Shortall, as a proof of the growing selfconfidence of the women but was also stressed by many of the interviewed women.

The strong orientation of the women on the family and the farm, however, inherent in their structural framework, remains unchanged. We have called this unusual form of emancipation, which deviates decisively from the usual, more urban and bourgeois concept of emancipation, in the words of one farming woman as "two-thirds emancipation" [27]. This paradox also seems to irritate other feminist researchers like Berit Brandth, "The issues of farm women's strained relationship to gender equality and feminism has continued to puzzle feminist researchers." [28] (p. 186).

\section{Balancing Personal Benefits and Costs}

When we shed light on the individual level, we can see that the women in this process (re)act not only as crisis managers. Their involvement should also be understood as a desire for self-realization and - following Hans Joas - for realizing their creative potential as well as their social competence [5]. The feminization of agriculture as commercialization of various spheres of the farm's 'female economy' increases the number of activities farming women enjoy 
[8] (p.209ff). The desire to organize and control their own work and to 'be their own boss' is an overriding concern for Martha B and her daughter-in-law. The development and expansion of the female economy offers these two but also other pluriactive women of the sample a framework in which they can put their experiences, preferences and passions to good use and which strengthens their self-confidence, as described by Flaminia Ventura in 1994 [29].

Wanda $\mathrm{C}$ and other interviewed farming women also stressed the welcome diversion and the interaction with the tourists as positive sides of agritourism. As they rather rarely go on holiday themselves (quite an interesting paradox with in agritourism), they enjoy their opportunity "to welcome the world" on their farm. It is stimulating and inspiring, not only for themselves but also for their children, who experience a broadening of their horizon [30].

As a negative consequence of the successful development and commodification of the female economy, especially the women choosing path (b) must cope with an increased workload and severe time pressure unless they manage to reorganize their schedules [7] (p. 99). In these cases the strategy of responding to the challenges of modernization in a traditional way by increasing family labour encounters its limits. The tendency towards 'self-exploitation', a characteristic of the peasant family economy, is connected with linking the status of entrepreneur and worker. Farm women are especially vulnerable to this tendency because of moral values they have inherited [31]. Relatively constant hard work was a significant constituent of farm women's selfimage and the image others had of them. If an illness, or even death, is added to the everyday workload, it can become particularly difficult and barely manageable.

In each case, the women involved need to find a good balance between the positive and the negative sides of the agritourism business if they want to benefit from their engagement in pluriactivity in the long term.

\section{Balancing Peasant and Entrepreneurial Principles}

Regarding their attitudes the presented and also other interviewed farming women of the sample sometimes set priority to peasant and sometimes to entrepreneurial principals with their creative actions. It depended on the changing demands and situations. Against van der Ploeg [6] (p. 113), who sometimes concedes similarities but usually quite sharply polarizes the peasant and the entrepreneurial modes of agriculture, we would like to stress that we could find the combination of both principles. In general, this generation of farming women developed entrepreneurial strategies to survive as farmers and to keep the farm in the family. They showed an extraordinary mutability. They accepted a slow but continuous change and modernized with traditional means, as Heide Inhetveen and Margret Blasche [8] (p. 232) had described earlier as a result of the base line study. The farming families were sceptical about rapid progress. Their dominant mode of coping with changes was to let things take their course and respond to them without giving up their principles: "We'll deal with it as it comes". This attitude is at the heart of peasant resilience.

Further to Hans Joas' theory of creativity of action, I would like to refer to Alexander Tschajanow's "theory of peasant economy" that states the peasant family's desire to reach a good balance between its consumption needs, its workload, which fluctuates through the family's life cycle, and individual interests $[18,31,32]$. Our sample supports this theory for instance by the fact that no families started up an agritourism or direct marketing business while their children were small, and only very rarely does the expansion of the business coincide with an expansion of the family as in the case study of Martha B. ${ }^{4}$ The benefits of a good balance might explain why farming families limit their business development.

One also should keep in mind that agritourism is just one part of people's pluriactivity mosaic. For a successful combination of all upcoming tasks, they have to decide not only with regard to economic surplus but also to a good use of other available resources, such as family labour, vacant buildings, existing networks and machinery, etc. In the end, every activity has to fit best into the time-tables of all involved family members.

\section{REGIONAL DEVELOPMENT SUPPORTED BY A WELL-BALANCED PARTNERSHIP OF AGRICUL- TURE AND TOURISM}

When the farming families presented here and other families in the sample open their farms and show the mainly urban people coming to their place the values of rural life, they play an important role for mutual appreciation and understanding of nature and cultivation, producers' and consumers' interests, in fact for integrating the rural and the urban. According to van der Ploeg, agriculture and society are becoming linked in new ways, which opens the possibility to unfold "a new cultural capital" [6] (p. 122). It would be complemented by the fact that the children of farmers often have dual or multiple qualifications which they make good use of on the family farm. This makes them paragons of a speeded-up society, in which even qualifications and trades have a short shelf life. "With its multiple options for change, the farm family business conforms to the post-modern society, which appears to its members as multioptional ("anything is possible") even if it isn't always" [33]. The question remains if the farming people will be able to turn this potential to their own advantage.

Up to now, the investigated farming families involved in agritourism have succeeded in increasing their autonomy. They also "tend to increase the added value produced on individual farms as well as in the agricultural sector as a whole." [6] (p. 156). Beyond that, there are several signs that this specific unfolding of the available resources might contribute to the quality of life in rural areas as perceived by rural dwellers (Ventura et al. [34] according to [6] p. 160ff.) and as a consequence will also secure endogenous regional development.

Our long-term study shows that agritourism can support the successful development even of a well-established old holiday region like Franconian Switzerland. Success is based on a well-functioning relationship between the agricultural

\footnotetext{
${ }^{4}$ Tschajanow's theory lacks the appropriate consideration of reproductive work [31] but I think its basic principles can be connected to gender claims and further developed.
} 
and the tourist sector as well as the forestry. On the one hand, agritourism benefits from the attractive landscape and its sightseeing and sports options. On the other hand, the active farms guarantee the cultivation of the landscape. Unlike in the Alps, tourism in Franconian Switzerland is less dependent on the traditionally farmed cultivated landscape. Therefore one can expect that a drop in the number of active farms would have a smaller impact on the economic success of the tourist industry. But with Hans Embacher I would like to stress that the tourist industry needs the agricultural sector, "not only for farming the landscape but also for additional tourist offerings. At the same time, farming families benefit from a tourist industry that provides jobs, supports regional infrastructure and development and, last but not least, buys agricultural and processed products. The fate of both sectors is intertwined in a unique way and their future will depend on their ability to develop a well-balanced partnership" [35] (p. 10). Another positive aesthetic influence is the fact that all farms of our sample offering agritourism were beautifully kept at the last visit. It can be read as a sign of their capability "to create a "beautiful farm"" [6] (p. 51). So we can confirm other observations from the Alps: where agritourism exists you will not find dilapidated farms [36]. This aspect should not be underestimated as support for rural tourism as well as for regional development in general.

In spite of the small amount that every farm contributes to the per capita gross national or regional product one should not dismiss its significance for the vitality of a region. Besides, unlike in high-frequency tourist destinations the total extent of tourist activities has remained within a very manageable scale and so far no negative impact has been suffered of the type that is know from studies in the Alps and in some Canadian regions: "What is often neglected is the risk assumed by the local inhabitants of the destination itself. The risk to them may be a dramatically altered lifestyle due to overcrowding, inflated prices including land and buildings, as well as noise and other forms of pollution" [37] (p. 32).

Given the external as well as internal adaptability of fulland part-time farms which we were able to document in our investigation, peasant farming will play an important role for food security as well as for sustainable regional development. Farming women who are pluri-active in farm and farm-related businesses, off-farm as well as in the peasant households, contribute substantially to "farm-based rural development" [38].

Given the increasing uncertainties of a globalized economy, pluriactivity in general and agritourism, and especially direct marketing, represent a successful combination of resources and an interesting work-life-balance concept for farming families. The current global economic and financial crisis might even benefit the agritourism farms. When tourists are increasingly looking for cheaper recreation and holiday offers, some of them might choose local alternatives such as agritourism.

Despite many scenarios forecasting the abandonment of farming, numerous family farms of different sizes and often in disadvantaged regions have survived until today. Its "survival culture" described by John Berger has manifested itself repeatedly and seems confirmed once again: "The re/markable consistency of farming experience and peasant world view gains an unprecedented and unexpected significance just at that moment when it seems threatened with extinction." [1] (p. 233).

\section{ACKNOWLEDGEMENTS}

The author is grateful to Heide Inhetveen who led the base line study. The two follow-up-studies were developed and conducted in close cooperation with her.

I would like to acknowledge the financial support from the DFG (German Research Foundation) and the Bavarian Ministry for Agriculture, Food and Forestry as well as the cooperation of all participating farming families. Thanks also to Brigitte Scott who edited the English version and to the anonymous reviewers for their constructive comments.

\section{REFERENCES}

[1] Berger J. SauErde: Geschichten vom Lande. Frankfurt/Main: Fischer 2004.

[2] Boučková B. Definition of Agritourism. AgroTourNet 'S Hertogen Bosch 2008. Download 2009 Octobre, 21. Avaiable from: agrotournet.tringos.eu/files/definition_of_agritourism.ppt.

[3] Shortall S. Economic Status and Gender Roles. In: Bock BB, Shortall S, Eds. Rural Gender Relations. Issues and Case Studies. Wallingford: CABI 2006; pp. 303-316.

[4] Weinberger-Miller P. Zukunftsperspektiven von Einkommensalternativen. In: Bayerische Landesanstalt für Landwirtschaft, Ed. Strategien zur Stärkung einer nachhaltigen und wettbewerbsfähigen Landbewirtschaftung in Bayern Landwirtschaft 2020, Teil 4: Mit mehreren Standbeinen die Existenz sichern. Freising-Weihenstephan 2007; pp. 61-94.

[5] Joas H. Die Kreativität des Handelns. Frankfurt/Main: Fischer 1996.

[6] Ploeg JD van der. The New Peasantries: Struggles for Autonomy and Sustainability in an Era of Empire and Globalization. London/Sterling, VA: Earthscan 2008.

[7] Inhetveen H, Schmitt M. Feminization Trends in Agriculture: Theoretical Remarks and Empirical Findings from Germany. In: Buller H, Hoggart K, Eds. Women in the European Countryside. Aldershot: Ashgate 2004; pp. 83-102.

[8] Inhetveen $H$, Blasche $M$. Frauen in der kleinbäuerlichen Landwirtschaft. Opladen: Westdeutscher Verlag 1983.

[9] 2009 July, 26. Available from: http://www.fraenkischeschweiz.com/

[10] Maier J, Troeger-Weiß G. Voraussetzungen und Vorleistungen der Gemeinden für eine Fremdenverkehrsentwicklung in peripheren Räumen. In: Bundesminister für Raumordnung, Bauwesen und Städtebau, Ed. Entwicklung ländlicher Räume durch den Fremdenverkehr: Forschungsberichte und Seminarergebnisse. Bonn-Bad Godesberg 1986; pp. 40-51.

[11] 2009 July, 26. Available from: http://kulturerlebnis-fraenkischeschweiz.de/seiteleader-aktionsgruppe.html).

[12] Bundesministerium für Ernährung, Landwirtschaft und Verbraucherschutz, Ed. Land- und Forstwirtschaft in Deutschland, Daten und Fakten 2008. Berlin 2008; p. 16.

[13] Bayerisches Staatsministerium für Landwirtschaft und Forsten, Ed. Bayerischer Agrarbericht 2008. München 2008; p. 32.

[14] O'Hara P. Out of the shadows: Women on family farms and their contribution to agriculture and rural development. In: Burg M. van der, Endeveld M, Eds. Women on family farms: Gender research, EC policies and new perspectives. Wageningen: Ceres 1994; pp. 49-66.

[15] Rossier R. Role models and farm development options: A comparison of seven Swiss farm families. In: Cristóvao A, Ed. European Farming and Society in Search of a New Social Contract - Learning to Manage Change: (Pre)Proceedings of the 6. European IFSA Symposium 2004; pp. 699-710.

[16] Gorman M. Gender relations and livelihood strategies. In: Bock BB, Shortall S, Eds. Rural Gender Relations: Issues and Case Studies. Wallingford: CABI 2006; pp. 27-46. 
[17] Fahning I. Frauen sind ein Gewinn! Beitrag der Frauen am Landwirtschaftlichen Gesamteinkommen. Hannover: Niedersächsisches Ministerium für Ernährung, Landwirtschaft und Forsten 2001.

[18] Tschajanow A. Die Lehre von der bäuerlichen Wirtschaft. Versuch einer Theorie der Familienwirtschaft im Landbau. Frankfurt/New York: Campus 1987/1923.

[19] Vonderach G, Ed. Neue Erwerbskombinationen auf dem Bauernhof. Aachen: Shaker Verlag 2006.

[20] Gasson R. Farm women in Europe: their need for off-farm employment. Sociol Ruralis 1984; 24: 216-28.

[21] Gasson R, Winter M. Gender Relations and Farm Household Pluriactivity. J Rural Stud 1992; 8(4): 387-97.

[22] Johnsen S. Contingency revealed: New Zealand farmers' experiences of agricultural restructuring. Sociol Ruralis 2003; 43(2): 128-53.

[23] Sachs CE. The invisible farmers: Women in agricultural production. Totowa NJ: Rowman \& Allanheld 1983.

[24] Modelmog I. Versuchungen: Geschlechtszirkel und Gegenkultur. Opladen: Westdeutscher Verlag 1994.

[25] Whatmore S. Farming Women: Gender, Work and Family Enterprise. Basingstoke, England: Macmillan 1991.

[26] Shortall S. Gender and Farming: An Overview. In: Bock BB, Shortall S, Eds. Rural Gender Relations: Issues and Case Studies. Wallingford: CABI 2006; pp. 19-26.

[27] Inhetveen H, Schmitt M. "Two-thirds emancipated": Persistence and change in action patterns of farm women on German small holdings In: Agricultural Research Institute, Ed. The New Challenge of Women's Role in Rural Europe: Proceedings of an International Conference, Nicosia, Cyprus 2001; pp. 301-307.

[28] Brandth B. Gender identity in European family farming: a literature review. Sociol Ruralis 2002; 42(3): 181-200.

[29] Ventura F. Women in Italian agriculture: Changing roles and arising problems. In: Burg M, van der, Endeveld M, Eds. Women on Family Farms: Gender Research, EC Policies and New Perspectives. Wageningen: Ceres 1994; pp. 27-40.
[30] Högl H. Hinter den Fassaden des Tourismus: Dörfer im Stress. Innsbruck: Österreichischer Studienverlag 1995.

[31] Inhetveen H. „Beträchtliche Mengen unausgenützter Zeit“: Zum Bild der Frau in A.W. Tschajanow's Theorie und Utopie einer bäuerlichen Wirtschaft. In: AG Ländliche Entwicklung/FB Stadtund Landschaftsplanung der GH Kassel, Ed. Die Wissenschaft und die Bauern. Rheda-Wiedenbrück: AbL Bauernblatt Verlag 1996; pp. 207-219.

[32] Peters A. Alexander Tschajanow's Theorie der bäuerlichen Familienwirtschaft: Thesen, Rezeption und Ansatzpunkte für eine Diskussion. In: AG Ländliche Entwicklung/FB Stadt- und Landschaftsplanung der GH Kassel, Ed. Die Wissenschaft und die Bauern. Rheda-Wiedenbrück: AbL Bauernblatt Verlag 1996; pp. 197-205.

[33] Inhetveen H. Ausbruch oder Aufbruch - Wohin bewegen sich die bäuerlichen Familienbetriebe? Sulzbürg: Vortragsmanuskript 2008.

[34] Ventura F, Milone P, Sabelli D, Autiello L. Agritourism in Umbria: building linkages and synergies in local economies. In: Ploeg JD van der, Long A, Banks J, Eds. Living Countrysides: Rural Development Processes in Europe: The State of the Art. Doetinchem, The Netherlands: Elsevier bedrijfsinformatie bv 2002; pp. 20-29.

[35] Embacher H. Tourismus und Landwirtschaft: Ideen säen - Erfolge ernten; eine Begleitbroschüre zur Wanderausstellung: Erfolgreiche Kooperationsmodelle zwischen Tourismus \& Landwirtschaft. Wien 1996.

[36] Greif F, Wagner K. Kooperation L \& T: Zusammenarbeit von Landwirtschaft, Tourismus und Freizeitwirtschaft. Wien: Fachverband d. Seilbahnen/Bundessektion Tourismus u. Freizeitwirtschaft d. Wirtschaftskammer Österreich 1995.

[37] George EW, Mair H, Reid DG. Rural Tourism Development: Localism and Cultural Change. Bristol/Buffalo/Toronto: Channel View Publications 2009.

[38] Ploeg JD van der, Long A, Banks J. Living Countrysides: Rural Development Processes in Europe; The State of the Art: Introduction. Doetinchem, The Netherlands: Elsevier bedrijfsinformatie 2002; pp. 7-17. 